\title{
Model of the Factors Influencing Competitiveness of the Latvian Fisheries Sector Cluster
}

\author{
Inese Biukšāne \\ Riga Technical University
}

\begin{abstract}
The aim of the research is to elaborate the model of factors influencing competitiveness of the Latvian fisheries sector cluster. Based on the studied scientific literature, the research provides an improved definition of the sector competitiveness and defines the factors influencing the competitiveness of the sector. As a result of the analysis, the author has discovered that there are several internal and external social, economic, political and environmental factors that influence the competitiveness of the Latvian fisheries sector cluster. It is advisable to the institutions involved in fisheries policy-making to take into account the identified factors, influencing the competitiveness, and their changes when making and improving the general policy of the sector.
\end{abstract}

Keywords - Competitiveness, fisheries sector cluster, model.

\section{INTRODUCTION}

The world economy faces changes mostly related to the processes of globalisation, uneven development of the countries, as well as reinforcement of competitiveness. Nowadays the competitiveness of some country's companies more and more determines and influences the development potential of each country. One of the key aims in the development strategy of countries, spheres and companies has become ensuring competitiveness (Škapars \& Šumilo, 2006). Assessment of competitiveness is a significant element in the evaluation of economic performance and sustainability of a sphere and its companies.

A fundamental characteristic of competitiveness lies in the fact that it contains social and economic, political and environmental consequences not only of the economic category (product, consumer and environment of rivals, etc.) but also of the non-economic category (systems of education, science, demography, politics and values, etc.), which determine the problems of evaluating thereof.

Authors' interpretations of competitiveness differ. Separate authors believe that only companies compete among themselves, not the countries; consequently, the basis of competitiveness is formed by the indicators of entrepreneurship effectiveness, including entrepreneurship strategies, management skills, marketing, efficiency of prices and costs. However, as we know, entrepreneurship is carried out by a company in a certain region, following the legislation of the area, and consequently many things depend on the measures carried out in the framework of the country and the created environment (Paula \& Titarenko, 2009, 15).

The experience of economic development all over the world has proven that competitiveness is influenced by many various factors. For a long time the factors of investment into the capital and infrastructure dominated. Later the neoclassical economists considered directing a resource flow to the "right" fields and "right" companies in the corresponding sphere to be the most important task. In the process of development of the science of economics, scientists supplemented the range of the viewed issues with several factors: human and social capital, technological progress and innovations, business relation to the development of the surrounding environment, nature of demand, diversification of products and market etc. Nowadays scientists working in the field of economics and entrepreneurship believe that the factors influencing the competitiveness are interrelated and should be evaluated in a common context (Kassalis, 2010c).

The author intends to analyse competitiveness, thus, offering a model of factors influencing the competitiveness of the cluster of the Latvian fisheries sphere within the present paper.

The aim of the paper is to elaborate the model of factors influencing the competitiveness of the cluster of the Latvian fisheries sphere.

To reach the aim, the following tasks have been set:

1. to study and analyse the nature of competitiveness of the sphere cluster and its definitions;

2. to identify the factors influencing the competitiveness of the sphere cluster;

3. to elaborate the model of factors influencing the competitiveness of the cluster of the Latvian fisheries sphere.

The object of the research is the competitiveness of the cluster of the Latvian fisheries sphere.

The subject of the research is factors influencing the competitiveness of the cluster of the sphere and their interrelation.

Research methods - the paper deals with the generally accepted theoretical research methods: analysis and synthesis, as well as the method of determining the indicators, comparison, grouping and graphic depiction.

The theoretical and methodological basis of the research consists of the works of the foreign and Latvian scientists, their studies and publications. The research also examines planning documents, reviews, and reports drawn up by the EU and Latvian state institutions.

\section{Nature of Competitiveness AND DEFINITION OF THE CONCEPT}

There are comparatively a few studies on the competitiveness of the sphere; moreover, as far as the competitiveness of the fisheries sector is concerned there are no studies at all. Often the concept "competitiveness" is used in the debates of policy of economics, where the associated meanings of the term often differ and in many cases are not shown clearly enough.

The concept of company competitiveness and its theoretical fundamentals have been developing historically for a long time that is why it has allowed defining various aspects of the concept of competitiveness. However, despite the contribution of many 
writers into the research of the nature of competitiveness, the author arrives at the conclusion that there is still no unified and generally accepted definition of company competitiveness and its evaluation methodology.

The concept "competitiveness" derived from the concept "competition", which in the Latin language "concurrentia" means "collision", "competition" (Mihailovs, 1999). The competitiveness theory was summarised by A. Smith, who was the first to define the concept of competitiveness as competition, formulating the main principle of competitiveness - "the concept of invisible hand". If we take competition as an emulative action of economic subjects, then competitiveness is "the subject's qualities, giving it an opportunity to complete the actions, which allow succeeding in the rivalry" (Mihailovs, 1999). Competitiveness along with the concept of competition is one of the most important categories describing the commodity and service market, as well as one of the most significant factors of entrepreneurship influencing any company in the economic sector (Fedotova \& Geipele, 2009).

The representatives of the International Monetary Fund believe that competitiveness is the ability of a company to produce and offer goods and services of international quality standards more cost effectively than other companies (Bella, Lewis \& Martin, 2007).

The World Economic Forum defines competitiveness as present-day and future ability and possibility of entrepreneurs to create the world commodities, possessing price and extra-price qualities, which are more attractive than of the other domestic and foreign competitors (World Economic Forum, 2009). In further reports by the World Economic Forum, competitiveness was defined as a set of institutions, policies and factors that determine the level of productivity of a county, thus setting the level of prosperity. The level of productivity also determines the rates of return obtained by investments in an economy, and consequently - the competitiveness of an economy (World Economic Forum, 2014b).

One of the most famous scholars in the field of economic competitiveness M. E. Porter believes that competitiveness should be viewed as productivity of a company (Porter, 1990). Companies and countries that are able to reach the necessary level of productivity obtain the competitive advantage (Kassalis, 2010c).

In the opinion of K. Fedotova K. and I. Geipele, competitiveness is an ability of a company, sector or country to sell its offer on the market. It is an indicator of successful company's activity, influencing the development of an enterprise and further growth prospective (Fedotova \& Geipele, 2009). Company's competitiveness is the ability to produce goods and to provide services of higher quality for lower costs compared to the ones offered by domestic and international competitors. Competitiveness is an acknowledgement of the price conformity of the company's produced goods and the production process efficiency (Kassalis, 2010c).

The winner of the Nobel Prize in economics S. S. Kuznets defines competitiveness as a long-term increasing productivity based on progressive technology and institutional and ideological corrections (Kuznets, 1971; 1973). In this case, S. S. Kuznets defines competitiveness as a body of factors determining the level of institutional, policy and state productivity measured as a level of productivity, setting also a sustainable welfare level evaluated by the society. A more competitive national economy is able to create a higher level of income to its inhabitants (Kuznets, 1971; 1973). The relation of competitiveness and productivity was studied by P. Krugman, who pointed out that competitiveness might be considered an absolute level of productivity and its dynamics (Krugman, 1994).

The Organisation for Economic Co-operation and Development in its study "Indicators of International Competitiveness: Conceptual Aspects and Evaluation" and the EU Strategy 2020 emphasised work productivity described as foundation of competitiveness, investments and welfare (Durand \& Giorno, 1987; Eiropas Komisija, 2010). Competitiveness means increase in productivity, which is the only way to achieve a sustained growth of income (per capita) that consequently increases the standard of living (European Commission, 2011; 2014; World Economic Forum, 2014a). The World Competitiveness Yearbook defines competitiveness in a much wider sense: economy manages the totality of its resources and competencies to increase the prosperity of its population (Institute for Management Development, 2012).

The United Nations Industrial Development Organization believes that the competitiveness of the sphere is evaluable and measurable as part of market (intensity of export) and added value per capita (United Nations Industrial Development Organization, 2013). In the foundation of achieving a high level of welfare, there are powerful market positions in separate specific spheres, based on academic work concerning policy of strategic trade sectors.

The Terminology Commission of the Latvian Academy of Sciences explains competitiveness as a degree of process compliance with the requirements of the chosen market according to technical, economic and other indicators. It is the proficiency of a company and its management in creating good commodity and service market, solving technology, production, service, human resources, practical skills and knowledge, strategic and calendar planning issues, as well as employing the right sale policy, good quality of production and service, high level of co-service etc. (Latvijas Zinātṇu akadēmijas Terminoloǵijas komisija, 2015).

The Centre for International Competitiveness, founded in 2007 and focused on the research of competitiveness of a company and economy, defines competitiveness as the capability of an economy to maintain increasing standards of living for those who participate in it, by attracting and maintaining firms with stable or rising market shares in an activity (Centre for International Competitiveness, 2015). Competitiveness in a region will depend on its ability to predict and successfully adapt to the internal and external social and economic challenges, ensuring new economic opportunities, including higher quality workplaces.

The author concludes that the sector competiveness is the ability to sell higher quality output (goods and services) on the market more efficiently than domestic and international competitors are able to do it. 


\section{IdentificAtion of the FaCtors Influencing the} Competitiveness of the Cluster of the Sphere

On the basis of the studies carried out by several scholars, the author concludes that competitiveness is influenced by various interrelated microeconomic and macroeconomic factors. In the studies, an increasing number of scholars emphasise various factors of specific spheres and their companies, which facilitate an activity. In this case, superiority of competitiveness of a sphere and companies in it takes the form of advantages and their identification.

M. E. Porter holds a view that a company must have sufficient and qualitative production factors (human resources, natural resources, knowledge potential, capital and infrastructure) in order to compete in the corresponding sphere (Porter, 1990). Production factors may vary depending on the specialisation of a company, and it is possible to supplement them in order to compensate disadvantages of separate factors.

Conditions and characteristics of demand factors (quality, volume, conformity with the development tendencies in the world market, etc.) may help to form advantages of competitiveness for the companies, thus creating more improved products and novelties and much quicker in comparison with the competitors (Porter, 1990).

Conversely, the spheres, which are related to support infrastructure or included in it, help develop more successfully providing various services and opportunities to the companies. These spheres ensure profitable contribution and provide an opportunity to take part in the process of modernisation, thus stimulating a company in a sphere to introduce novelties (Porter, 1990).

Related companies and the spheres included in support infrastructure depend on the development of leading companies in a sphere. When leading companies of a sphere are developing, both related companies and the spheres included in the support of infrastructure benefit.

Environment of the cluster facilitates the formation of healthy mutual competition and the increase of common competitiveness both in the local and foreign markets (Kassalis, 2010c). In the environment of the cluster, the integrated long-term development of companies may be observed at the horizontal and vertical levels; as a result, not only competitiveness of the companies in a sphere increases but also competitiveness of a region and country (Oxford Research, 2008; Rīgas Starptautiskā ekonomikas un biznesa administrācijas augstskola, 2008; Kassalis, 2010a; 2010b).

Success and competitiveness of a company depends on the characteristics of foundation, organisation and management of a company, as well as on the competition level at which a company performs (Porter, 1990).

M. Porter also emphasises the role of two other factors which may influence competitiveness; they are - the government and random events. The government may influence the tax and investment policy, local market and competition among the companies, conditions for import and export, legislation, etc. Intervention of the state may occur at the local, regional, state, and international levels. The reason for the evaluation of political processes and their performance is the fact that the measures, which are considered productive and promotional, may turn out to be less productive or even non-productive in practice due to inefficient structure of institutions (Devarajan, Swaroop \& Zou, 1996). Lack of formation of politics and its influence upon competitiveness may rather indicate the insufficient structure of an institution than a policy itself (Acemoglou, Johnson, Robinson \& Thaicharoen, 2003; Acemoglou \& Robinson, 2010).

Conversely, a company has considerable difficulties to predict random events (for instance, natural disasters), and they are practically uncontrollable. Random events may have huge influence upon competitiveness of the companies since they can cause interruption in production; as a result, some companies lose their position of competitiveness, but others - gain (Porter, 1990).

However, the World Bank experts are of opinion that competitiveness shall be evaluated taking into account 3 basic issues: macro factors, material and non-material infrastructure, which define offer (World Bank, 2009).

To be able to increase its competitiveness, a company has to create and maintain a competitive advantage, which distinguishes it from other companies in a specific sphere.

Maintenance of the environment of competitiveness is an essential driving force of competitiveness and growth in current conditions of fierce global competition - it facilitates a desire and abilities of companies to create new products, optimise costs, use new technologies and innovations or, in simple terms, to perform more efficiently. It is important to reorient mutual competition from competition of basic level to competition that is based on advantages arising from development of efficient and sustainable processes and formation of high added value (Kassalis, 2010c). Usually, only those companies that are successful in the internal market are able to succeed in export markets (Regionālās attīstības un pašvaldību lietu ministrija, 2006).

Growth of national economy is ensured by the increase of economic welfare of population of a country over a longer period which is based on human work (Smith, 1759). Performing in a stable economic and political environment, the growth of national economy may be facilitated by an increase in provision of production factors; as a result, volume of production and productivity of employees increase (Charles \& Douglas, 1928).

A company may increase its competitiveness if it uses production factors, which are at its disposal, in an efficient manner and is able to produce high-quality production at a lower prime cost in comparison with other companies in the same sphere, as well as sells it on the market at the prices that attract consumers (Caune, Dzedons \& Pētersons, 2003; Priede, 2010).

To be able to offer competitive production in a globalised world when competition is increasing, a company has to direct its economic activities towards the usage of innovations and technologies, which are related to novelties (Tirupati, 2008). One of the main ways how to develop a sphere and increase competitiveness of its companies in the future is to support innovations and facilitate collaboration with the science (Latvijas Valsts agrārās ekonomikas institūts, 2013; 2014b). Knowledge shall be transformed into innovations (Reynolds, 1999; Romer, 2003). Environment of competition requires companies to turn to innovations (including novelties in the cultural and social field), which are one of the main driving forces of new economy that is directed towards knowledge (Latvijas Investīciju un 
attīstības aǵentūra, 2007). The usage of new technologies during the production process facilitates international trade (potential of export) and productivity of labour (Regionālās attīstības un pašvaldību lietu ministrija, 2006; Rostow, 1960). Exporting producers and innovative companies facilitate an increase of competitiveness (Gorodnichenko \& Schnitzer, 2010). Conversely, work efficiency depends on psychophysiological welfare of the employees that may have direct or indirect influence upon competitiveness of a company (Voronovs, 2013).

In the international market prices, costs and wages influence competitiveness (Draghi, 2012). Innovations focus on involvement of highly qualified professionals and every creative person in economic activities; as a result, new products and services with high added value occur in the global, regional and local markets, thus ensuring a significant increase in gross domestic product and formation of new workplaces (Latvijas Investīciju un attīstības aǵentūra, 2007). Innovations are necessary in order to avoid economic stagnation (Pasinetti, 1981).

Formation of provision and making investments play a significant role in economy; it facilitates improvement of common employment and increase of economic welfare of population (Solow, 1956). Investments in innovations are the quickest way how to develop the national and state economy in general (Atkinson, Livesey \& Milward, 1998; Boronenko, 2009). Thus, in order to increase competitiveness of a company over a short period and gain advantages of competitiveness, the usage of logistics is essential (Toyli, Hakkinen, Ojala \& Naula, 2008). Electrification and modernisation of multimodal transit corridors (transit routes, railway and ports) shall be carried out (Pārresoru koordinācijas centrs, 2012). Transport infrastructure influences productivity of all sectors of national economy; thus, investment in infrastructure would have a significant impact on an increase of competitiveness (Nijkamp \& Poot, 2004).

Improvement of energy efficiency of the production and service sector is the issue of both competitiveness and quality of work and environment (Pārresoru koordinācijas centrs, 2012).

The main success factor of a company is profit; however, in order to gain it, increasing sales volume shall be ensured by lowering production costs that may be done with the help of marketing activities (Fedotova \& Geipele, 2009) and the appropriately chosen marketing strategy (Simpson \& Taylor, 2002). Taking into account the fact that implementation of marketing activities in a company is a complicated process which is influenced by various internal and external factors (for instance, lifetime of a company, the aim, knowledge and attitude of company's manager, competition, etc.), company's management shall choose the most efficient marketing strategy, as a result of which financial parameters of a company are influenced positively (simpson, Padmore, Taylor \& Frecknall-Hughes, 2006). The companies succeed in business if they are able to satisfy needs and expectations of the consumers by implementing an efficient marketing strategy and activities subordinated to it (Webster, 1981; 1992; 2002; Moorman \& Rust, 1999; Becherer, Halstead \& Haynes, 2003; Berthon, Ewing \& Napoli, 2008).

To increase competitiveness, formation of powerful and dominant brands plays a special role; they serve as a mark of identification, identity and quality for a company (Webster, Malter \&
Ganesan, 2003; Kassalis, 2010c; Latvijas Valsts agrārās ekonomikas institūts, 2014a). Formation of company's image is an important element of public relations (Kotlers, 2006), which creates competitive advantages for the companies. In a case when a positive company's image is created, a company has an opportunity to gain a wider range of consumers and collaboration partners rather than in a case when a negative company's image is created. Formation of a successful and positive company's image shall be based on comprehensive, easily perceptible and unambiguous company's logo, slogan and visual elements (layout of premises, visiting cards, design of various documents and information sources, etc.), and economic activities of a company shall be oriented towards the principles and rules of morality, which are generally accepted in the society.

Frequently, exactly the lack of knowledge and experience in the companies hinder them from efficient work; therefore, they face problems when competing with foreign companies possessing decades of experience (Fedotova \& Geipele, 2009). Besides, transformation of knowledge and contacts from the world's leading universities by inviting various lecturers is an efficient way of education development and internationalisation (Troen, 1992). Cooperation plays a significant role in facilitation of exchange of knowledge and experience (Kučinskis, 2004; 2009; Boroṇenko, 2009). A company cannot achieve high competitiveness operating in isolation - collaboration with other companies, state institutions and other organisations may have a positive influence upon the efficiency of a company, and is necessary (Kassalis, 2010c). French theorist G. Charles maintained: "Cooperation is a daughter of poverty and mother of prosperity" (Charles, 1891). As a result of cooperation, work productivity, quality and income increase, new workplaces are created, time and energy are saved, education, inculcated togetherness and need for common benefit are promoted; consequently, the national economy develops as a whole (Kučinskis, 2004; 2009; Engels, 2011). The principle of performance of cooperatives is: "One for all and all for one!" (Kučinskis, 2004; 2009). Collaboration shall be based on the loyalty and initiative (Fedotova \& Geipele, 2009). Events supporting competence (seminars, trainings, excursions, etc.), facilitating the process of knowledge and experience exchange among the companies, are important (Athiyaman \& Parkan, 2008).

Competitiveness is also influenced by the reasons why entrepreneurship is set up. There are two main types of entrepreneurship: motivated by a chance (entrepreneurship is set up in order to take an opportunity to get higher income or due to a desire to become independent) or motivated by a necessity (entrepreneurship is set up since another alternative to get income does not exist). Entrepreneurship motivated by a chance facilitates competitiveness in long-term development the best since it has a greater contribution (Acs \& Varga, 2004).

One of the most important factors in ensuring competitiveness of the companies is the combination of culture, which is oriented towards a market, and flexible planning strategy - efficient combination of internal organisational elements: strategy, culture, climate, processes and procedures (Alpkan, Yilmaz \& Kaya, 2007). Different strategy is a competitive strategy (Porter, 1996); it is the driving force of any sphere or organisation (Lukaszewski, 2006). Strategy is a long-term programme of a company 
within the framework of which mission, aims and tasks of a company are elaborated by evaluating possible factors of internal and external influence and examining company's resources and methods (Mintzberg, James \& Ghoshal, 1997; Katlips, Senters \& Brūms, 2002; Gorodnichenko \& Schnitzer, 2010), which help a company to position itself outwards (Accenture Foundation, School of Communication Management and Banyan, 2009). Strategic planning shall definitely be open for new ideas, new information sources and new opportunities, thus allowing a company to react quickly to the variations of environment. Its aim is to ensure an increase in the company's value in the long term on the basis of the strategies at the functional, business, global and corporate levels, which are implemented by a company in order to create and maintain advantages of competitiveness (Pleša, 2011).

In the Latvian Competitiveness Report, it is stated that the factors influencing competitiveness are institutional quality, macroeconomic policy, production factors, education and skills, infrastructure of innovations, the government (tax system, administrative efficiency, role of the government, etc.), population (demography, etc.), product markets (context of strategy and competition), infrastructure and energy (Rīgas Ekonomikas augstskola, 2012). Provision of high quality and rise in work productivity are the most important conditions to increase the competitiveness of entrepreneurs; therefore, entrepreneurs shall be encouraged to regularly evaluate efficiency of the usage of their resources, productivity of employees' labour and innovation potential in order to export products and services which are processed as much as possible and have increased value rather than export resources in the form of raw materials (Pārresoru koordinācijas centrs, 2012).

The factor that is the most important for advantage of competition in most spheres, especially in advanced economies, where an increase of productivity is essential, is process assistance created within the state, which differs from the spheres of other countries, and not inherited assistance.

\section{Model of Factors Influencing the Competitiveness of the Cluster of the Latvian Fisheries Sector}

On the basis of the literature analysis, the author of the paper has elaborated the model of factors influencing the competitiveness of the cluster of the sphere (Fig. 1). The elaborated model shows the factors influencing competitiveness.

The author arrives at a conclusion that the competitive advantage of the cluster is its efficiency and its increase, which are based on the chosen development strategy and aims, and a set of actions duly carried out, taking into account the available production resources and events in the world.

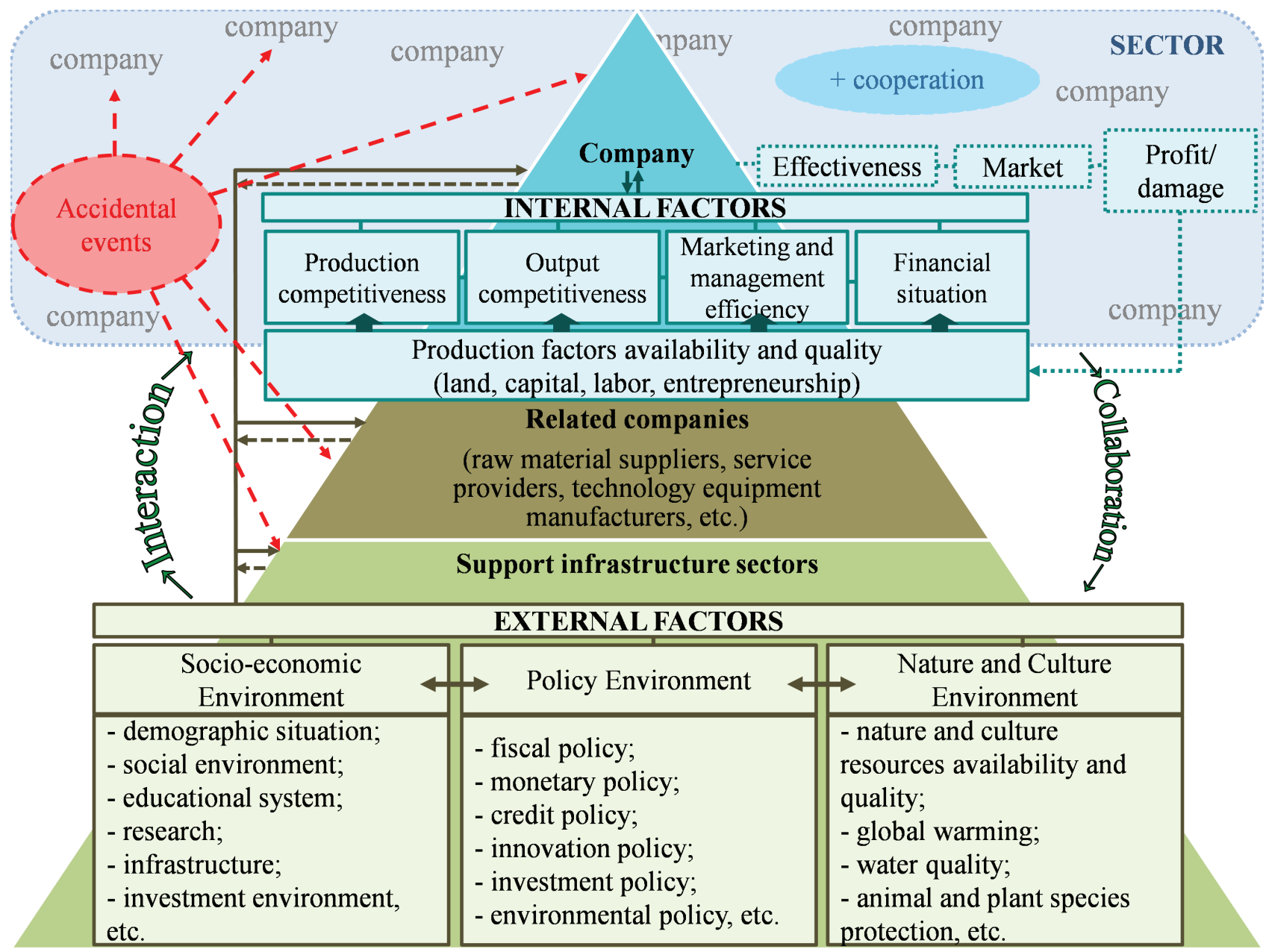

Fig. 1. Model of the factors influencing competitiveness of the Latvian fisheries sector cluster (created by the author) 
The competitive advantage allows companies to differ from other companies in the sector, thus providing an opportunity to hold a leader position. It should be taken into account that competitive advantage should not only be maintained, but also regularly revised, analysed and improved not to provide the competitors with the possibilities of growth in the environment of fierce competition. In this case companies must be dynamic, being in a continuous process of cognition and development; thus, companies will be able not only to increase their own competitiveness, but also competitiveness of the entire sector in the long term.

The author arrives at a conclusion that the competitiveness of the Latvian Fisheries Sector Cluster is affected by the production factor availability and their usage efficiency, various internal and external social, economic, political, natural and cultural, environmental (including random events) factors and the ability to adapt them, cooperation and development of mutual interaction and cooperation forms. It is impossible for companies to exist independently and be isolated from the surrounding environment and the factors influencing them under the market circumstances; therefore, formation of a strong cluster plays a significant role.

In this case, the competitiveness of a country directly depends on the competitiveness of every company working in a specific economic sector. The more competitive companies in a certain sector, the more competitive the corresponding sphere, and consequently the more competitive the country at the world level (Škapars \& Šumilo, 2006; Labklājības ministrija, 2007; Deņisovs \& Judrupa, 2008; Bočkova, 2009).

\section{Conclusion}

Sector competiveness is the ability to sell high quality production on markets more efficiently than domestic and international competitors are able to do it.

Competitiveness of the Latvian Fisheries Sector Cluster is affected by the availability of production factors and the efficiency of their usage, various internal and external social, economic, political, natural and cultural environmental factors (including random events) and the ability to adapt them, cooperation and formation of mutual interaction and cooperation forms and relationship among affiliated companies and support infrastructure spheres.

\section{REFERENCES}

Accenture Foundation, School of Communication Management, \& Banyan (2009). Strategic Research and Political Communications for NGOs: Initiating policy change. India: SAGE Publications India.

Acemoglou, D., \& Robinson, J. (2010). The Role of Institutions in Growth and Development. Review of economics and institutions. 1(2), 1-33. http://dx. doi.org/10.5202/rei.v1i2.1

Acemoglou, D., Johnson, S., Robinson, J., \& Thaicharoen, Y. (2003). Institutional causes, macroeconomic symptoms: volatility, crises and growth. Jour nal of Monetary Economics. 50, 49-123. http://dx.doi.org/10.1016/S03043932(02)00208-8

Acs, Z. J., \& Varga, A. (2004). Entrepreneurship, Agglomeration and Technological Change. Papers on Entrepreneurship, Growth and Public Policy, 1-28.

Alpkan, L., Yilmaz, C., \& Kaya, N. (2007). Market Orientation and Planning Flexibility in SMEs: Performance Implications and an Empirical Investigation. International Small Business Journal. 25(2), 152-172. http://dx.doi. org $/ 10.1177 / 0266242607074518$

Athiyaman, A., \& Parkan, C. A. (2008). Functionalist Framework for Identifying Business Cluster: Applications in Far North Queensland. Journal of Management. 33(1), 201-229. http://dx.doi.org/10.1177/031289620803300110

Atkinson, B., Livesey, F., \& Milward, B. (1998). Applied Economics. London: International Ltd. http://dx.doi.org/10.1007/978-1-349-14250-7
Becherer, R. C., Halstead, D., \& Haynes, P. J. (2003). Marketing orientation in SMEs: effects of the internal environment. New England Journal of Entrepreneurship. 6(1), 1-10.

Bella, G. D., Lewis M.\& Martin, A. (2007). Assessing Competitiveness and Real Exchange Misalignment in Low-Income Countries (IMF Working Paper WP/07/201). International Monetary Fund. Retrieved July 1, 2015, from https://www.imf.org/external/pubs/ft/wp/2007/wp07201.pdf

Berthon, P., Ewing, T. M.\& Napoli, J. (2008). Brand management in small to medium size enterprises. Journal of Small Business Management. 46(1), 27-45. http://dx.doi.org/10.1111/j.1540-627X.2007.00229.x

Bočkova, S. (2009). Uzñēmumu konkurētspējas prakstiskās novērtēšanas galvenie izaicinājumi un iespējas. Retrieved July 4, 2015, from http://koet.syktsu. $\mathrm{ru} / \mathrm{vestnik} / 2009 / 2009-1 / 2 / 2 . \mathrm{htm}$

Boronenko, V. (2009). Klasteru loma regiona konkurētspējas paaugstināšanā. The role of Clusters in the Development of Regional Competitiveness. (Promocijas darba kopsavilkums, Latvijas Lauksaimniecības universitāte. Summary of Doctoral thesis, Latvia University of Agriculture Faculty of Economics). Retrieved July 1, 2015, from http://llufb.llu.lv/dissertation-summary/regional-development/Vera_Boronenko_Promocijas_darba_kopsavilkums 2009 LLU_EF.pdf

Caune, J., Dzedons, A., \& Pētersons, L. (2003). Stratēgiskā vadīšana. Rīga: Kamene.

Centre for International Competitiveness. (2015). About The Centre for International Competitiveness. Centre for International Competitiveness. Retrieved July 1, 2015, from http://www.cforic.org/index.php

Charles, G. (1891). Principles of Political Economy. Boston: D. C. Heath\&Co.

Charles, W. C., \& Douglas, P. H. (1928). A Theory of Production. The American Economic Review. 18(1), 139-165.

Deņisovs, M., \& Judrupa, I. (2008). Reǵionu attīstības un konkurētspējas novērtēšana. Rīga: RTU Izdevniecība.

Devarajan, S., Swaroop, V., \& Zou, H. (1996). The composition of public expenditure and economic growth. Journal of Monetary Economics. 37, 313-344. http://dx.doi.org/10.1016/S0304-3932(96)90039-2

Draghi, M. (2012). Competitiveness of the euro area and within the euro area. Germany: European Central Bank. Retrieved July 5, 2015, from http://www. ecb.europa.eu/press/key/date/2012/html/sp120313.en.html

Durand, M., \& Giorno, C. (1998). Indicators of international competitiveness: conceptual aspects and evaluation (Economics Department Working Paper No. 195). France: $O E C D$. Retrieved July 7, 2015, from http://www.oecd.org/ eco/outlook/1864948.pdf

Eiropas Komisija. (2010). Komisijas zinojums. Eiropa 2020: Stratēgija gudrai, ilgtspējīgai un iekl̦aujošai izaugsmei. Brisele: EK. Retrieved July 9, 2015, from http://ec.europa.eu/eu2020/pdf/1_LV ACT part1_v1.pdf

Engels, F. (2011). Inovatīiās ekonomikas ū kooperā̄ijas principu modeḷa ieviešana Latvijā ilgtspējīgas attīstības veicināšanai. Retrieved July 16, 2015 , from http://www.tautasforums.lv/?p=3671

European Commission (2011). European Competitiveness Report 2011 (Commission Staff Working Document). Luxembourg: Publications Office of the European Union. Retrieved July 2, 2015, from http://aei.pitt.edu/45446/1/ competitiveness 2011.pdf

European Commission. (2014). European Competitiveness Report 2014 (Commission Staff Working Document). Luxembourg: Publications Office of the European Union. Retrieved July 2, 2015, from file:///C:/Users/biuksane/ Downloads/141003\%20ECR2014\%20OPOCE\%20full.pdf

Fedotova, K \& Geipele, I. (2009). Possibilities to Increase Competitiveness in Changeable Environmental Conditions. 50. RTU Starptautiskās zinātniskās konferences ziņojumu tēžu krājums. 22-23.

Forands, I. (2000). Stratēgíija. Kvalitāte. Rīga: Latvijas izglīīibas fonds.

Gorodnichenko, Y.,\& Schnitzer, M. (2010). Financial Constraints and Innovation: Why Poor countries Don't Catch Up (NBER Working Paper series). Cambridge: National Bureau of Economic Research. Retrieved July 4, 2015, from http://www.nber.org/papers/w15792.pdf

Institute for Management Development. (2012). Malaysia in the World Competitiveness Yearbook 2012. IMD. Retrieved July 3, 2015, from http://www. pemudah.gov.my/documents/10124/431567/IMD+World+Competitiveness+Yearbook+\%28WCY\%29\%202012+1.pdf

Kassalis, I. (2010a). Cluster Based Approach: a Tool to Enter into the Market. The $6^{\text {th }}$ International Scientific Conference 'Business and Management 2010' selected paper, 635-Škapars \& Šmilo, 20062. http://dx.doi.org/10.3846/ bm.2010.084

Kassalis, I. (2010b). Industrial Clusters: an Opportunity to Stimulate Business Entities Integration and Competitiveness. Economic Science for Rural Development. Economic Science for Rural Development proceedings. 23, 14-21.

Kassalis, I. (2010c). Uzñēmumu konkurētspējas paaugstināšanas iespējas Latvijas tautsaimniecībā. Latvijas Universitātes raksti. 754, Bella, Lewis \& Martin, 2007-22

Katlips, S. M., Senters, A. H., \& Brūms, G. M. (2002). Sabiedriskās attiecības. Rīga: Avots.

Kotlers, F. (2006). Mārketinga pamati. Rīga: Jumava.

Krugman, P. (1994). Competitiveness: A dangerous obsession. Foreign Affairs. 73(2), 28-44. http://dx.doi.org/10.2307/20045917

Kučinskis, J. (2004). Kooperācijas attīstība Latvijā un pasaulē: idejas, vēsture, perspektīvākie attīstības virzieni. Rīga: Latvijas Hipotēku un zemes banka.

Kučinskis, J. (2009). Kooperācija un vēlreiz kooperācija. Retrieved July 16, 2015, from http://www.tautasforums.lv/?p=1140 
Kuznets, S. S. (1971). Economic Growth of Nations. Total Output and Production Structure. Harvard: Harvard University Press. http://dx.doi. org/10.4159/harvard.9780674493490

Kuznets, S. S. (1973). Population, Capital and Growth: Selected Essays. New York: Norton.

Labklājīibas ministrija. (2007). Latvijas un tās regionu darba tirgus specifiskās problēmas (ES struktūrfondu Nacionālās programmas 'Darba tirgus pētī jumi' projekts 'Labklājības Ministrijas pētījumi’ Nr. VPD1/ESF/NVA/04/ NP/3/1/5/1//0001/0003). Labklājības ministrija. Retrieved July 13, 2015, from http://www.lm.gov.lv/upload/darba tirgus/darba tirgus/petijumi/regionu specifiskas_problemas.pdf

Latvijas Investīciju un attīstības agentūra. (2007). Inovatīvās darbības pamatelementi.: rokasgrāmata maziem un vidējiem uznēmumiem. Rīga: LIAA. Retrieved July 10, 2015, from http://www.liaa.gov.lv/files/liaa/attachments/31_inovativas_darbibas_pamatelementi.pdf

Latvijas Valsts aḡārās ekonōmikas institūts. (2013). Stratēg giskais ietekmes uz vidi novērtējums Eiropas Jürlietu un Zivsaimniecības fonda Rīcības programmai 2014.-2020. gadam: vides pārskata projekts. LVAEI. Retrieved July 11, 2015, from https://www.zm.gov.lv/public/ck/files/ZA EJZF RP SIVN.pdf

Latvijas Valsts agrārās ekonomikas institūts. (2014a). Rīcības programma Eiropas Jūrlietu un zivsaimniecības fonda ieviešanai 2014.-2020. gadā: Ex-ante novērtējums. LVAEI. Retrieved July 11, 2015, from https://www. zm.gov.lv/public/files/CMS_Static_Page_Doc/00/00/00/49/13/ZN_Ex-ante novertejums.pdf

Latvijas Valsts agrārās ekonomikas institūts. (2014b). Stratēgiskais ietekmes uz vidi novērtējums Eiropas Jürlietu un Zivsaimniecības fonda Rīcības programmai 2014.-2020. gadam: vides pārskata projekts. LVAEI. Retrieved July 11, 2015, from https://www.zm.gov.lv/public/files/CMS Static_Page Doc/00/00/00/49/12/ZN Strategiskais ietekmes SIVN.pdf

Latvijas Zinātnu akadēmijas Terminoloğijas komisija (2015). Akadēmiskā terminu datubāze 'AkadTerm': konkurētspēja. Retrieved July 1, 2015, from http://termini.lza.1v/term.php?term=konkur $\% \mathrm{C} 4 \% 93 \mathrm{tsp} \% \mathrm{C} 4 \%$ 93ja\&list=konkur $\% \mathrm{C} 4 \% 93 \mathrm{tsp} \% \mathrm{C} 4 \% 93 \mathrm{ja} \&$ lang $=\mathrm{LV}$

Lukaszewski, J. (2006). Let's get serious about strategy. Retrieved July 1 , 2015, from http://www.e911.com/strategy/Synopsis-PR Reporter-Strategy-1_Lets Get Serious About_Strategy.pdf

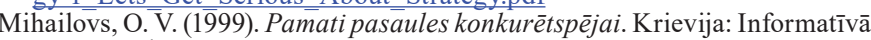
grāmata Plus.

Mintzberg, H., James, B. Q., \& Ghoshal, S. (1997). The strategy process. Prentice Hall International.

Moorman, C., \& Rust, R. T. (1999). The Role of Marketing. Journal of Market ing. 63, 180-197. http://dx.doi.org/10.2307/1252111

Nijkamp, P., \& Poot, J. (2004). Meta-analysis of the effect of fiscal policies on long-run growth. European Journal of Political Economy. 2(1), 91-124. http://dx.doi.org/10.1016/j.ejpoleco.2003.10.001

Oxford Research. (2008). Cluster policy in Europe. A brief summary of clus ter policies in 31 European countries. Oxford Research. Retrieved July 22 2015, from http://www.clusterobservatory.eu/system/modules/com.gridnine opencms.modules.eco/providers/getpdf.jsp?uid=100146

Pārresoru koordinācijas centrs. (2012). Latvijas Nacionālais attīstības plāns 2014.-2020. gadam. PKC. Retrieved July 1, 2015, from http://www.pkc gov.lv/images/NAP2020\%20dokumenti/20121220 NAP2020 apstiprinats Saeima.pdf

Pasinetti, L. L. (1981). Structural change and economic growth: a theoretical essay on the dynamics of the wealth of nations. Cambridge: Cambridge University Press.

Paula, D., \& Titarenko, D. (2009). Latvijas ekonomikas konkurētspēja un investīciju nozīme tās veicināšanā. Rīga: LU Akadēmiskais apgāds.

Pleša, S. (2011). Stratēǵiskā biznesa vadība un biznesa attīstības iespējas Lietuvas-Latvijas pārrobežu reǵionā (mācību materiāls). Retrieved July 18, 2015 , from file:///C:/Users/biuksane/Downloads/Biznesa vad\%C4\%ABba.pdf

Porter, M. E. (1990). The Competitive Advantage of Nations. New York: The Free Press. http://dx.doi.org/10.1007/978-1-349-11336-1

Porter, M. E. (1996). What Is Strategy? Harvard Business Review. Retrieved July 21, 2015, from https://hbr.org/1996/11/what-is-strategy

Priede, J. (2010). Latvijas tautsaimniecības nozaru eksporta kvalitātes konkurētspējas analīze. Latvia's economical branches exports quality competitiveness analysis. (Promocijas darba kopsavilkums, Latvijas Universitāte. Summary of Doctoral thesis, Latvia University). Retrieved July 12, 2015, from http://www.lu.lv/fileadmin/user_upload/lu_portal/zinas/ Priede kopsavilkums.pdf

Reǵionālās attīstības un pašvaldību lietu ministrija. (2006). Latvijas $\mathrm{Na}$ cionālais attīstības plāns 2007.-2013. gadam. RAPLM. Retrieved July 12, 2015, from http://www.innovation.lv/wp-content/uploads/2013/10/Latvijas Nacionalais attistibas plans 2007-2013.pdf

Reynolds, P. D. (1999). Creative destruction: source or symptom of economic growth? Entrepreneurship, Small and Medium-sized Enterprises and the Macroeconomy. Cambridge: Cambridge University Press.

Rīgas Ekonomikas augstskola. (2012). Latvijas konkurētspējas novērtējums 2011. REA. Retrieved July 12, 2015, from http://biceps.org/assets/docs LCR LV 1804 Final 1.pdf

Rìgas Stärptautiskā ekonomikas un biznesa administrācijas augstskola. (2008). Latvijas tautsaimniec̄̄bas nozaru ar augstu koncentrācijas līmeni un bar jerām ienākšanai tirgū noteikšana. RSEBAA. Retrieved July 19, 2015, from http://www.kp.gov.lv/documents/f33262ef6d2160993e11c9368f1fd8f40d b9396d
Romer, P. M. (2003). The Origins of Endogenous Growth. Journal of Economic Perspectives. 8(1), 3-22. http://dx.doi.org/10.1257/jep.8.1.3

Rostow, W. W. (1960). The Stages of Economic Growth: A Non-Comunist Manifesto. Cambridge: Cambridge University Press. Retrieved July 17, 2015 , from http://www.ou.edu/uschina/gries/articles/IntPol/Rostow.1960.Ch2.pdf Simpson, M., \& Taylor, N. (2002). The role and relevance of marketing in SMEs: towards a new model. Journal of Small Business and Enterprise Development. 9(4), 370-382. http://dx.doi.org/10.1108/14626000210450559

Simpson, M., Padmore, J., Taylor, N., \& Frecknall-Hughes, J. (2006). Marketing in small and medium sized enterprises. International Journal of Entrepreneurial Behavior \& Research. 12(6), 361-387. http://dx.doi. org/10.1108/13552550610710153

Škapars, R., \& Šmilo, $\bar{E}$. (2006). Latvijas ekonomikas un sabiedrības pārstrukturizācijas ietekme uz uzn̄èmējdarbības konkurētspēju un iedzīvotāju dzīves kvalitāti. Rīga: LU Akadēmiskais apgāds.

Smith, A. (1759). The Theory of Moral Sentiments. London: Online Library of Liberty. Retrieved July 15, 2015, from http://dx.doi.org/10.1093/oseo/ instance.00042831

Solow, R. M. (1956). A Contribution to the Theory of Economic Growth. The Quarterly Journal of Economics. 70(1), 65-94. http://dx.doi. org/10.2307/1884513

Tirupati, D. (2008). Role of Technological Innovations for Competitiveness and Entrepreneurship. Journal of Entrepreneurship. 17(2), 103-115. http:// dx.doi.org/10.1177/097135570801700201

Toyli, J., Hakkinen, L., Ojala, L., \& Naula, T. (2008). Logistics and financial performance: An analysis of 424 Finnish small and medium-sized enterprises. International Journal of Physical Distribution \& Logistics Management. 38(1), 57-80. http://dx.doi.org/10.1108/09600030810857210

Troen, S. I. (1992). Higher Education in Israel: an Historical Perspective. Higher Education. 23, 45-63. http://dx.doi.org/10.1007/BF00141144

United Nations Industrial Development Organization. (2013). The Industrial Competitiveness of Nations (Competitive Industrial Performance Report). UNIDO. Retrieved July 29, 2015, from https://www.unido.org/fileadmin/ user media/Services/PSD/Competitive Industrial_Performance Report UNIDO 2012 2013.PDF

Voronovs, D̄. S. (2013). Uznēmuma konkurētspējas izvērtēšana un analīze: uznēmuma konkurētspējas esošo novērtēšanas metožu pārskats. Retrieved July 4, 2015, from http://www.cfin.ru/management/strategy/competit/analysis2.shtml\# ftn5

Webster, F. E, Mălter, A. J., \& Ganesan, S. (2003). Can marketing regain its seat at the table? (Reports). Marketing Science Institute. Retrieved July 12, 2015 from http://www.msi.org/reports/can-marketing-regain-its-seat-at-the-table/

Webster, F. E. (1981). Top management's concerns about marketing: issues for the 1980 s. Journal of Marketing. 45(3), 9-16. http://dx.doi.org/10.2307/1251538

Webster, F. E. (1992). The changing role of marketing in the corporation. Journal of Marketing. 56(4), 1-17. http://dx.doi.org/10.2307/1251983

Webster, F. E. (2002). Marketing management in changing times. American Marketing Association. Retrieved July 12, 2015, from https://archive.ama.org/ archive/ResourceLibrary/MarketingManagement/Pages/2002/11/1/5Mihailovs, Durand \& Giorno, 1998; 997986.aspx

World Bank. (2009). Clusters for Competitiveness. A Practical Guide \& Policy Implications for Developing Cluster Initiatives. Retrieved July 29, 2015, from http://siteresources.worldbank.org/INTRANETTRADE/Resources/ cluster initiative pub web ver.pdf

World Ecoñomic Forum (2009). The Global Competitiveness Report 2009-2010. Switzerland: World Economic Forum. Retrieved July 8, 2015, from http:// www3.weforum.org/docs/WEF_GlobalCompetitivenessReport_2009-10. pdf

World Economic Forum. (2014a). The Europe 2020 Competitiveness Report. Switzerland: World Economic Forum. Retrieved July 5, 2015, from http:// www3.weforum.org/docs/WEF Europe2020 CompetitivenessReport 2014. pdf

World Economic Forum. (2014b). The Global Competitiveness Report 2014-2015. Switzerland: World Economic Forum. Retrieved July 7, 2015 , from http://www3.weforum.org/docs/WEF_GlobalCompetitivenessReport 2014-15.pdf

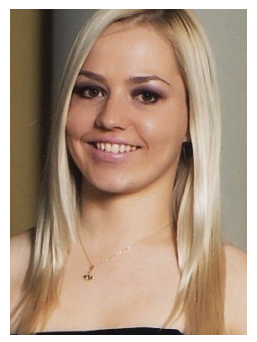

Inese Biukšāne. Since 2012 she has been undertaking Doctoral studies at Riga Technical University. In 2012 she acquired Master's degree in Economics (specialisation: International and Regional Economics) at Riga Technical University. In 2010 she received Bachelor degree in Economics (specialisation: Finance and Accounting Management) from Rezekne Higher Education Institution. Since 2012 she has been working as an Economist at the Latvian State Institute of Agrarian Economics. Scientific interests: the EU financial instruments, regional and international economics, financial economics, competitiveness, modelling, fisheries (fishery, aquaculture, fish processing).

Address: Struktoru Str. 14, Riga, LV-1039, Latvia, telephone: +371 29566569. E-mail: inese.biuksane@inbox.lv 